\title{
Polymerase Chain Reaction Detection of ASFV Infection in Nigerian Indigenous Pig
}

\author{
Olufunke 0. Oluwole1, Galman 0. Omitogun² \\ ${ }^{1}$ Institute of Agricultural Research and Training, Obafemi Awolowo University, Ile-Ife, Nigeria \\ ${ }^{2}$ Faculty of Agriculture, Animal Science Department, Obafemi Awolowo University, Ile-Ife, Nigeria \\ Email: oluwafunmike@yahoo.co.uk
}

Received 2 May 2014; revised 1 June 2014; accepted 26 June 2014

Copyright (C) 2014 by authors and Scientific Research Publishing Inc.

This work is licensed under the Creative Commons Attribution International License (CC BY).

http://creativecommons.org/licenses/by/4.0/

(c) (i) Open Access

\begin{abstract}
This work investigated the presence of African Swine Fever Virus (ASFV) in Nigerian Indigenous Pig (NIP) using Polymerase Chain Reaction (PCR) screening method on the extracted DNA from the pig blood. NIP population selected from south western Nigeria were used for this study. ASFV infected blood samples collected from the University of Ibadan were used as positive control. Adiscrete and specific band was observed in both NIP and the infected samples show the presence of ASFV in NIP. The bands were of the expected size 278 base pairs (bp). The implication of this finding is that NIPs have domiciled ASFV without showing any clinical symptoms.
\end{abstract}

\section{Keywords}

Nigerian Indigenous Pig, Polymerase Chain Reaction, African Swine Fever

\section{Introduction}

The population of pig in Nigeria increases from 2 million in 1984 to 7 million in 1997 before the widespread of ASF epizootic [1]. The Nigerian Indigenous Pig (NIP) is becoming extinct as livestock genetic resource due to the high rate of genetic erosion which is caused by extensive indiscriminate and unplanned mating with exotic pig breeds. It has been acknowledged that the NIP is resistant to African Swine Fever but it has not been scientifically investigated and documented.

Disease is one of the factors that affect the livestock production in Nigeria [2]. Jovanoic et al., 2009 [3] stated that diseases can have a significant impact on animal productivity and production, human health and, consequently, on the overall process of economic development. Pigs harbour a range of parasites and diseases, some of which are zoonotic. One of these is the African Swine Fever that is caused by a virus.

African Swine Fever (ASF) is a highly contagious viral disease of pigs and of such concern that it is included 
among the List A Diseases by the United Nations Office International des Epizooties (OIE) [4]-[8]. It causes a devastating haemorrhagic fever of pigs with mortality rates approaching 100 per cent with the acute and peracute forms. It causes major economic losses, threatens food security and limits pig production in affected countries. The disease causes significant economic losses in affected countries due to the high mortality rates associated. The transmission of the disease, as it now occurs in sub-Saharan Africa, is through the African soft tick (Ornithodoros moubata porcinus) and warthogs or domestic pigs. The transmission through the warthog and soft ticks does not occur in west Africa, although ASF virus has been detected from warthog in Nigeria of West Africa [8], and the presence of soft ticks is also confirmed [7]. This study aimed at screening of pure Nigerian Indigenous Pigs in the piggery unit of Institute of Agricultural Research and Training (I.A.R.T.) in Ibadan. The specific objective is to verify disease resistance of Nigerian Indigenous Pigs (NIP) to African Swine Fever.

\section{Materials and Methods}

Blood samples (5 ml each) of 20 pure Nigerian Indigenous Pigs (NIP) were collected from the jugular vein into anticoagulant containers. The DNA extraction was done by using DNA kit (Zymobeads). Diagnostic Polymerase Chain Reaction was performed according to the Manual of Diagnostic Tests and Vaccines [6]. ASF-specific primers (oligonucleotide primers) targeting the major capsid protein (VP72 gene) amplifying a 278-bp fragment within the conserved region was employed: PAS $_{1} \mathrm{~F}$ : 5'-ATG GAT ACC GAG GGA ATA GC-3' and PAS 2 R: 5'-CTT ACC GAT GAA AAT GAT AC-3' [6] [9]. The final reaction volume of $25 \mu$ PCR master mix comprised $10 \mu \mathrm{l}$ extracted DNA template, $10 \mu \mathrm{l}$ Nuclease Free Water, $10 \mu \mathrm{l}$ oligonucleotide primers (for both Forward and Reverse) and $12 \mu \mathrm{l}$ of already prepared Master Mix. Each tube was placed in an automated PCR thermal cycler (MG48+; Mygene ${ }^{\mathrm{TM}}$ Series) for amplification for 35 cycles as follows: initial denaturation at $94^{\circ} \mathrm{C}$ for 3 minutes for 35 cycles, with 3 steps of denaturation at $94^{\circ} \mathrm{C}$ for 30 seconds, annealing at $57^{\circ} \mathrm{C}$ for 45 seconds and extension at $72^{\circ} \mathrm{C}$ for 30 seconds and final extension at $72^{\circ} \mathrm{C}$ for 5 minutes. Amplification products were analyzed by electrophoresis on a $1 \%$ agarose gel containing $0.5 \mu \mathrm{g}$ of ethidium bromide per $\mathrm{ml}$. The gel were visualized under Ultra violet light and photographed.

\section{Results and Discussions}

From the Polymerase Chain Reaction for molecular investigation, a discrete and specific band of the expected size 278 base pair (bp) was observed for NIP in lane 5 and in lane 6 where discrete band was observed for infected animal collected from University of Ibadan as positive control. No band was observed in lane 7 as negative control in Figure 1. The result showed that pure NIP was also infected with ASFV without showing any clinical symptoms.

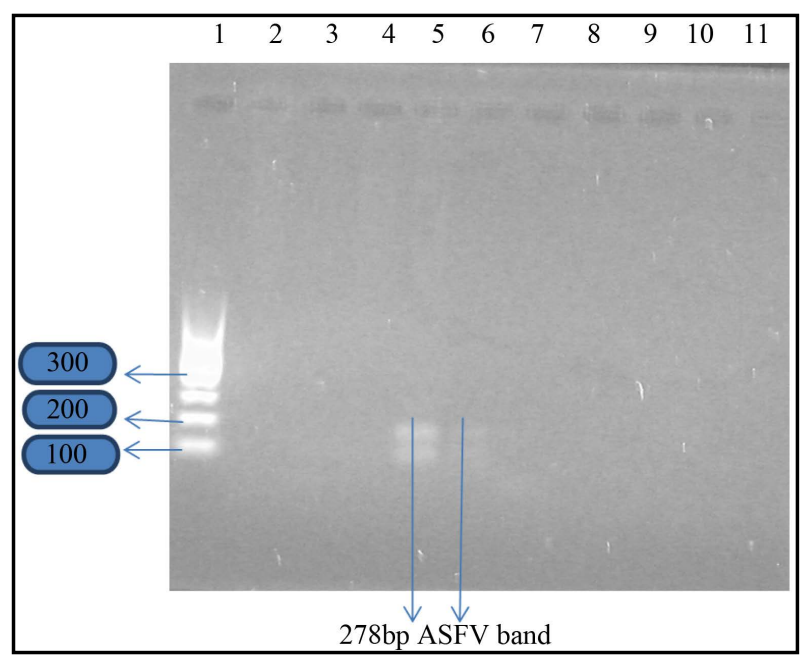

Figure 1. Amplification at 278 bp of ASFV in NIP at lane 5, infected sample from University of Ibadan as a positive control at lane 6 and lane 7 showing the negative control without the DNA. Molecular marker (100 bp) is at lane 1. 
The 278 bp of ASFV observed in NIP was corroborated by the findings of Luther et al. (2007) and Luther et al. (2008) [9] [10], where the same virus band was observed in Bushpigs and warthogs were tested at National Veterinary Research Institute (NVRI), Jos. The resistance of NIP to ASFV for long period without any clinical symptom or death was explained by Adeoye and Adebambo as the ability of host to trap ASFV within their tissues by the activities of macrophages that eat up the pathogens and infected tissues so that other parts and their mast cells in the tissues are not affected.

This observation was also explained by the work of Adeoye and Adebambo (2010) where serological tests were carried out on ASF outbreak survivors, their offspring and $\mathrm{F}_{2}$ showed a decline in antibody levels against ASF from $100 \%$ to $18.79 \%$. This phenomenon was explained as the ability of engulfed ASFV to be broken down easily and effectively by macrophages leading to decreasing circulation of ASFV in the blood and other tissue. Thus, the amount of shed ASFV particles observed in urine and faeces was seen to drop significantly in their offspring [11]. This observation was also corroborated by Olugasa et al. (2007) [12] who also reported that level of infection in the serum dropped from $96.8 \%$ in the stock to $13.8 \%$ in young stock. The ability of the virus to persist in one host while killing another genetically related host has been established by Palgrave et al. (2011) [13] where a particular sequence found in warthog and bush pigs was absent in domestic pigs.

From this study, it can be concluded that NIP has ASFV but do not exhibit any clinical sign. This also establishes the role of NIP in the epidemiology of ASF in Nigeria. There is however the question of defining NIP so called "resistance" to ASFV as whether it is "resistant" or "tolerant". An animal as a host can only evolve two types of defense mechanism to increase its fitness when challenged with pathogen which are resistance and tolerance [14] [15]. It is important to distinguish between these two defense mechanisms in NIP because they have different pathological and epidemiological effects. An increased understanding of tolerance to pathogen infection could lead to more efficient treatments for infectious diseases and a better description of host-pathogen interactions. Jovanovic (2009) [3] defines resistance as ability of an animal to resist infection (which means that the virus will not be seen in the animal), while tolerance signifies a condition in which the host is infected by the pathogen but displays very limited adverse effects. By this definition, we can classify NIP as being tolerant.

Both host resistance and tolerance enhance host fitness but major difference between the two is important in genetic improvement programme. The effects of resistance and tolerance can lead to striking difference in epidemiological and evolutionary outcomes in affected animals.

Disease control strategy using genetic improvement to obtain host resistance is better than disease control strategy using breeding to obtain host tolerance. This is because of their different epidemiological and evolutionary consequences, meaning that the ASF eradication in a population can only be achieved through increasing resistance while the tolerance will not restrict ASF replication [16]. It has been argued that selective breeding may be more evolution-proof than manipulations in resistance because tolerance does not impose selection for pathogen counter-measures. FAO (2012) also stated that the breeding for increased resistance to ASFV may be possible, but there are several factors to be considered before embarking on such a program. One consideration is that resistant pigs that are unable to be infected by ASFV will be difficult to achieve. It is more likely that pigs will express a phenotype that will not succumb to the clinical effects of ASFV. While these type pigs may not express clinical disease, they may become infected and could shed ASFV into the environment. As such, these pigs could pose a risk to susceptible pigs in the area or undermine control strategies. Instead transcriptome analysis of ASFV-infected macrophages using microarrays can be used which will provide new candidate genes that are differentially regulated during infection. Such candidate genes could be used for development of DNA marker tests for selection of animals with reduced susceptibility to disease. Therefore conservation of resistant breeds is critical for progress in genetic resistance to ASFV.

\section{References}

[1] Dafwang, I.I., Adebambo, O.A. and Adesehinwa, A.O.K. (2010) Status of Pigs Production and Marketting in Nigeria: An Overview of Current Practises, Problems and Prospects. First Nigerian International Pig Summit, Ibadan, 22-25 November 2010, 1-17.

[2] Abubakar, M.B., Ngele, D.J.N. and Achaji, M.B. (2003) Problems of Annual Livestock Production in Nigeria. A Case Study of Akko Local Government Area of Gombe State. Proceedings of the 28th Conference of the Nigerian Society for Animal Production, 71-73.

[3] Jovanović, S.M., Savić1, D. and Živković, M. (2009) Genetic Variation in Disease Resistance among Farm Animals. Biotechnology in Animal Husbandry, 25, 339-347. http://dx.doi.org/10.2298/BAH0906339J 
[4] Owolodun, O.A., Bastos, A.S., Antiabong, J.F., Ogedengbe, M.E., Ekong, P.S. and Yakubu, B. (2010) Molecular Characterisation of African Swine Fever Viruses from Nigeria (2003-2006) Recovers Multiple Virus Variants and Reaffirms CVR Epidemiological Utility. Virus Genes, 41, 361-368.

[5] Sanchez-Vizcaino, J.M., Martinez-Lopez, B., Martinez-Aviles, M., Martins, C., Boinas, F., Vial, L., Michaud, V., Jori, F., Etter, E., Albina, E. and Roger, F. (2009) Scientific Review on African Swine Fever. Scientific Report Submitted to EFSA, 1-141.

[6] OIE (World Organisation for Animal Health) (2008) Manual of Diagnostic Tests and Vaccines for Terrestrial Animals. 5th Edition, OIE, Paris, 957. http://www.oie.int/eng/en index.htm

[7] Penrith, M.L., Thomson, G.R., Bastos, A.D.S., Phiri, O.C., Lubisi, B.A., Du Plessis, E.C., Macome, F., Pinto, F., Botha, B. and Esterhuysen, J. (2004) An Investigation Intonatural Resistance to African Swine Fever in Domestic Pigs from an Endemic Area in Southern Africa. Review Science Technology of International Office Epizoonotic, 23, 965-977.

[8] Food and Agriculture Organization of the United Nations (FAO) (2010) The State Capacities of Animal Genetic Resources Management, Rome.

[9] Luther, N.J., Udeama, P.G., Majiyagbe, K.A., Shamaki, D., Antiabong, J., Bitrus, Y., Nwosuh, C.I. and Owolodun, O.A. (2007) Polymerase Chain Reaction (PCR) Detection of the Genome of African Swine Fever Virus (ASFV) from Natural Infection in a Nigerian Baby Warthog (Phacochoereus aethiopicus). Niger. Veterinary Journal, 28, 63-67.

[10] Luther, N.J., Udeama, P.G., Majiyagbe, K.A., Shamaki, D., Antiabong, J., Bitrus, Y., Nwosuh, C.I. and Owolodun, O.A. (2008) Detection of African Swine Fever virus genomic DNA Nigerian Red River Hog (Potamocho erusporcus). Veterinary Research, 160, 58.

[11] Adeoye, A.O. and Adebambo, A.O. (2010) Evaluation of Litter Traits of Pigs in an African Swine Fever (ASF) Prone Environment. Proceedings of First Nigerian International Pig Summit, Institute Animal Science, Institute of Agricultural Research and Training, Moor Plantation, 114-124.

[12] Olugasa, B. (2007) Serological Evidence of African Swine Fever Virus Infection in Commercial Pig Heard in South West Nigeria. African Journal of Livestock Extension, 5, 61-64.

[13] Palgrave, C.J., Gilmour, L., Lowden, S., Simon, G., Martha, L., Mellencamp, A. and Whitelaw, C.A. (2011) Pathogenesis Potential Role in African Swine Fever Underlies Differences in NF-kB Activity: A Species-Specific Variation in RELA. Journal of Virology, 85, 6008. http://dx.doi.org/10.1128/JVI.00331-11

[14] Doeschl-Wilson, A. (2012) Should We Aim for Genetic Improvement in Host Resistance or Tolerance to Diseases, 9-17.

[15] Food and Agriculture Organization of the United Nations (FAO) (2010) The State Capacities of Animal Genetic Resources Management Rome.

[16] Roy and Kirchner (2000) Evolutionary of Dynamics of Pathogen Resistance and Tolerance. Evolution, 54, 51-63. 
Scientific Research Publishing (SCIRP) is one of the largest Open Access journal publishers. It is currently publishing more than 200 open access, online, peer-reviewed journals covering a wide range of academic disciplines. SCIRP serves the worldwide academic communities and contributes to the progress and application of science with its publication.

Other selected journals from SCIRP are listed as below. Submit your manuscript to us via either submit@scirp.org or Online Submission Portal.
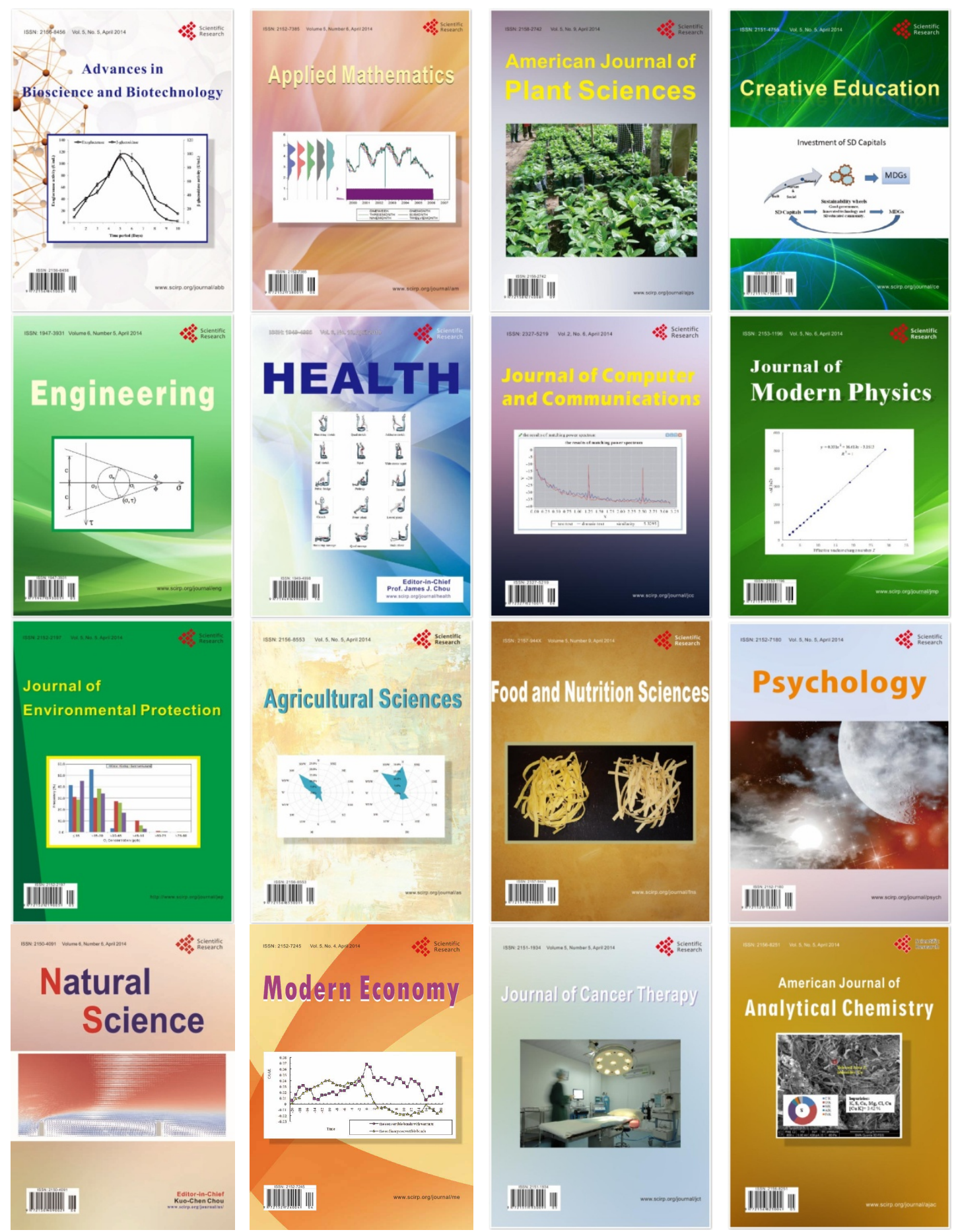